\title{
Jesuit Contributions to Biological Sciences in India
}

\author{
Leo D'Souza \\ St Aloysius College, Mangaluru, India \\ labens.sac@gmail.com
}

\begin{abstract}
Jesuits in India have made significant contribution to studies in classical as well as modern biology. The earlier classical studies resulted in the compilation of well-known and highly appreciated floras. In recent times, Jesuits have kept pace with the current trends in biology and have made contributions in the areas of environmental awareness, biodiversity, conservation, biotechnology, molecular biology, bioremediation, and bioenergy as well as biopesticides.
\end{abstract}

\section{Keywords}

biodiversity - taxonomy - biotechnology - tissue culture - conservation environment - genetics - molecular biology - environmental awareness

\section{$1 \quad$ Introduction}

The first Jesuits landed in Goa, India, in 1542, sent by Ignatius of Loyola (c.14911556) under the leadership of Francis Xavier (1506-52). The primary mission of the Jesuits wherever they were sent was evangelization, but this did not mean that they catered only to spiritual needs, for they were also concerned about the welfare of the people in other fields. One of these was the practical application of their knowledge of biology to introduce and develop various useful crops. Since they were mostly of Portuguese origin and had connections with Brazil, they imported several tropical fruit species and worked at breeding them to adapt them to the climate of the region. 
According to Charles Julius Borges (b.1950), "The Jesuits introduced many new plants from South America, of which cashew was the most valuable. Others were the pineapple, the potato, the guava, and the custard apple. About the year 1575, they also took to mango-grafting, which brought in much income."1 This is confirmed by plant explorer Wilson Popenoe (1892-1975), who states that "Jesuits at Goa were the first to apply scientific grafting techniques to the mango and when a new mango came into being, it was christened with the name of its grafter. The Jesuit contribution was considered so valuable that a mango variety Jesuita was named after the religious order." ${ }^{2}$

Besides such practical studies, from around $185^{\circ}$ to 1950, informal studies were conducted in the field of what is today known as biodiversity by the professors of philosophy of the Jesuit Philosophate, Sacred Heart College, Shembaganur, nestled in the Palni range of the Western Ghats. ${ }^{3}$ Although they had no formal training in natural sciences, their interest and dedication made up for it to a great degree. John Mallat (1862-1922) was especially interested in insects and made a large collection of insects of the Palni region. Emile Gombert (1866-1948) collected orchid plants and established a garden that was dedicated to these flowers on the campus of the college. Louis Anglade (1873-1953) surveyed and listed the flora and fauna of the Palni hills he documented through paintings. He prepared 1,910 color plates, which were bound in ten volumes. He also prepared a library of three hundred specimens of timbers. George Foreau (1889-1959) made a collection of mosses, lichens, algae, and fungi; nearly 424 species of moss were collected by him alone, and he had them identified by specialists from France. ${ }^{4}$ These collections of Anglade, Foreau, and others are housed and still available for visitors at the museum of the college.

The Jesuit professors also instilled a love of nature in the young men studying to be priests at Shembaganur. They were encouraged to make collections of the flora and fauna of the area on holidays. Many of these students, including

1 Charles J. Borges, The Economics of the Goa Jesuits, 1542-1759: An Explanation of Their Rise and Fall (New Delhi: Concept Publishing Company, 1994), 35.

2 Wilson Popenoe, Manual of Tropical and Subtropical Fruits (New York: The Macmillan Company, 1921), 78 .

3 Koyapillil Mathai Mathew, "Natural History Contributions of Madurai Jesuits," in Jesuit Presence in Indian History, ed. Anand Amaladass (Anand: Gujarat Sahitya Prakash, 1988), 249-74.

4 George Foreau, The Moss Flora of the Palni Hills (Bombay: Bombay Natural History Society, $1961), 13-47$. 
the present author, were inspired to take up higher studies in biology even though their natural inclinations lay elsewhere. ${ }^{5}$

\section{Contributions of Classical Biologists}

Systematic contributions in the field of biology began after colleges were opened in the headquarters of the British provinces, St Joseph's College, Tiruchirappalli, in 1844, St Xavier's College, Kolkata, in 186o, St Xavier's College, Mumbai, in 1869, and well-trained professors from Europe arrived in India to teach in them. One of the first of these was the Swiss Jesuit, Ethelbert Blatter (1877-1934) who came to India in 1903 to teach at St Xavier's College, Mumbai (then Bombay). Besides his teaching, he studied the palms of his adopted country. He first published a series of articles titled, The Palms of British India and Ceylon, and later published them as a book. ${ }^{6}$ Some Beautiful Indian Trees was published after he shifted to Panchgani in the Western Ghats after his retirement, first as a series of papers and later as a book. ${ }^{7}$ Some of the other books written by him were Beautiful Flowers of Kashmir in two volumes, The Flora of the Indus Delta, and The Ferns of Bombay. ${ }^{8}$

The contributions of Blatter to biology are found not only in his books but also in the extensive botanical collection he built up at St. Xavier's College, Mumbai. The Blatter Herbarium is an internationally recognized herbarium for taxonomic studies and allied branches in botany. It is one of the best herbaria in India holding collections of algae, fungi, bryophytes, pteridophytes, gymnosperms, and flowering plants ranging from the year 1816 onwards. It has a total of three million plant specimens and is listed in the Index herbariorum published by KEW—-Royal Botanic Gardens. In 1930, Blatter received the first Johannes Bruehl Memorial Medal of the Asiatic Society of Bengal for "conspicuous important contributions to the knowledge of Asiatic Botany."

Ferdinand Caius (1877-1944) worked first in St Joseph's College, Tiruchirappalli, and later at St Xavier's College, Mumbai. He had a wide range of interests,

5 Leo D'Souza, “Confessions of a Jesuit Botanist," Jivan 19 (2002): 21-24; D'Souza, "Dialogue in the Laboratory," Jivan 16 (1999): 13-16.

6 Ethelbert Blatter, The Palms of British India and Ceylon (London: H. Milford, 1926).

7 Ethelbert Blatter and Walter Samuel Millard, Some Beautiful Indian Trees (Bombay: Natural History Society, 1954).

8 Ethelbert Blatter, Beautiful Flowers of Kashmir, vol. 1 (London: J. Bale Sons \& Danielson Limited, 1927); Blatter, Beautiful Flowers of Kashmir, vol. 2 (London:John Bale Sons and Danielson Limited, 1928); Blatter et al., The Flora of the Indus Delta (Calcutta: Indian Botanical Society Journal, 1899); Blatter and J. F. D'Almeida, Ferns of Bombay (Bombay: MD Publications, 1932). 
including Indian medicinal plants, poisonous reptiles, the venom of scorpions, anti-venomous serums, the bacterial action of phenols, and organic compounds of mercury. He also conducted extensive studies of the medicinal and poisonous varieties of the subcontinent's palms, as well as medicinal and poisonous plants, such as mangoliads and dilleniads. His books Indian Plant Remedies Used in Snake-Bite and The Medicinal and Poisonous Plants of India were compilations of papers originally published by him in the Journal of Bombay Natural History Society, 1935-44, and later as books are still standard reference volumes. ${ }^{9} \mathrm{He}$ also made a study of medicinal and poisonous ferns..$^{10}$ Streptomyces caiuseae, a microorganism secreting the antibiotic streptomycin that is catalogued in the Bergey's manual, is one of the early discoveries from the Caius Laboratory, named after him at St Xavier's College.

Hermenegild Santapau (1903-70) from Spain joined the teaching staff of St. Xavier's College in 1940. He carried out research projects in Baluchistan, Kathiawar, and the Dangs Forest, exploring the mountain ranges of the Western Ghats, the Eastern Ghats, and the Eastern Himalayas, in addition to the districts of Assam, Darjeeling, Dehradun, and Mussoorie. Some of the well-known floras among the large number of scientific publications of Santapau are: The Flora of Khandala in the Western Ghats of India (1953), The Flora of Purandhar (1958), The Flora of Saurashtra, part 1 (1962), The Orchids of Bombay (1966)."

Santapau was associated with National Institute of Sciences of India, Linnaean Society, London, Indian Botanical Society, Royal Asiatic Society of Bengal, Botanical Society of Bengal, Bombay Natural History Society, Indian Science Congress Association, Phytopathological Society of India, International Society of Pythomorphology, International Association for Plant Taxonomy, International Association of Botanical Gardens, Royal Agricultural and Horticultural Society of Bengal, etc. He served on some of the committees appointed by the Council of Scientific and Industrial Research (CSIR), Indian Council of Medical Research (ICMR) and the Indian Council of Ayurvedic Research.

$9 \quad$ Ferdinand Caius and Krishnaji Shripat Mhas-kar, Indian Plant Remedies Used in SnakeBite (Calcutta: Thacker, Spink and Co., 1931); Caius, The Medicinal and Poisonous Plants of India (Jodhpur: Scientific Publishers, 1986 reprint).

10 Caius, "The Medicinal and Poisonous Ferns of India," Bombay Nat. Hist. Soc. (1935): 341-61.

11 Hermenegild Santapau, S.J., The Flora of Khandala on the Western Ghats of India (Delhi: Botanical Survey of India, 1967); Santapau, Flora of Purandhar or an Enumeration of All Phanerogranic Plants Discovered in Purandhar during the Years 1944-1956 (New Delhi: Oxford Book and Stationery Co., 1957); Santapau, ed., The Flora of Saurashtra, vol. 1: Ranunculaceae to rubiaceae (Rajkot: Saurashtra Research Society, 1962); Santapau and Kapadia, The Orchids of Bombay (Delhi: Government of India Press, 1966). 
The first Birbal Sahani Medal was bestowed on him by the Indian Botanical Society in 1964. In a well-deserved tribute to the memory of the late Hermenegild Santapau, the prime minister of India, Mrs. Indira Gandhi (1917-84), wrote on January 22:

In Rev. Santapau's death we have lost an eminent scholar who has served education and science for over 40 years. His deep love for India urged him to become a citizen of the country. He had a great knowledge of, and concern for, our plant wealth and wrote intensively on it for experts and laymen. May his memory long continue to inspire all those interested in our flora. ${ }^{12}$

Joseph Pallithanam (1915-84) was one of the first native Indian Jesuit botanists. He collected more than ten thousand plant specimens and published approximately eighty research papers on the subject of taxonomy. His Pocket Flora of the Sirumalai Hills, South India is a useful guide to botanists as well as tourists. ${ }^{13}$

Koyapillil Mathai Mathew (1930-2004) evolved a modern, illustrated regional flora of southern India. He carried out extensive field work in four zones. The first zone covered the vegetation of the plains and low altitude hills $(<400 \mathrm{~m})$ including eight out of nine tribal belts of Tamilnadu State. This was published as The Flora of the Tamil Nadu Carnatic (1981, 1982, 1983, and 1988), which contains 1905 plates and 2,939 pages of detailed text. A total of 2,020 species was covered in this work. ${ }^{14}$ In the second zone, a similar illustrated flora covered the montane region of the Palni hills, published as The Flora of the Palni Hills (1996-99; three volumes in five parts) with 1,233 plates of illustrations and 2,144 pages of text covering 2,478 species. ${ }^{15}$

Mathew had covered virtually the entire Deccan Plateau, which today is one of the botanically best-known regions in India. These volumes have received international acclaim for their comprehensive field coverage, detailed illustrations, updated nomenclature, and thorough treatment of each species. Field

\footnotetext{
12 Cited in P. V. Bole, "Rev. Fr. Hermenegild Santapau, S.J.," Taxon 4 (1970): 576-83.

13 Joseph Pallithanam, S.J., and Koyapillil Mathai Mathew, S.J., A Pocket Flora of the Sirumalai Hills, South India (Tiruchirapalli: Rapinat Herbarium, St Joseph's College, 2001).

14 Koyapillil Mathai Mathew, ed., The Flora of Tamil Nadu Carnatic, 4 vols. (Tiruchirapalli: Rapinat Herbarium, St Joseph's College, 1981-88).

15 Koyapillil Mathai Mathew, Flora of Palni Hills, 3 vols. (Tiruchirapalli: Rapinat Herbarium, St Joseph's College, 1996-99).
} 
floras, also called excursion floras first in English, later in the local language, Tamil, were aimed at delivery of knowledge of plants to ordinary people.

The belief was that teaching local people to recognize the plants around them is essential for involving them in nature conservation and eco-restoration. Just before his untimely death, Matthew was planning a six-volume illustrated Flora of North Tamil Nadu, completely revising the Carnatic series and extending to the border of Andhra State for more adequate field coverage. His mammoth publications include more than twelve volumes and 175 research papers. He had completed twenty-one major research projects funded by leading international and national agencies supporting peninsular floristics and environmental education. While reviewing his Materials for a Flora of the Tamilnadu Carnatic (1981), Radcliff-Smith remarked, "This is a most commendable project and the complete work will undoubtedly become a valuable reference, for although by no means covering such a large area as Gamble's Flora of Madras, it will nevertheless have dealt with the Flora of the area chosen in much greater depth and detail."16 Mathew described four new species, one subspecies, and proposed quite a few new combinations. A new species, Strobilanthes matthewiana R. W. Scotland, was named in his honor. He helped many botanists by providing Latin translations for new taxa. ${ }^{17}$

Cecil Saldanha (1926-2002) compiled the Flora of Hassan District, which is a compact work covering the botanically unexplored area of the Western Ghats of peninsular India. ${ }^{18}$ Saldanha and Dr. Dan Nicolson (1933-2016) of the Smithsonian Institution, Washington, DC undertook extensive field and laboratory studies on the flora of the area. In this book, 1,700 species of vascular plants have been reported. It has 132 original drawings and twenty color plates. According to Dr. K. Sankara Rao (b.1939), Herbarium in-Charge of the Indian Institute of Science, Bengaluru:

Cecil J. Saldanha was an ardent lover of plants and a great explorer endowed with thorough knowledge of species and habitats. He was very committed to structuring Flora of Hassan District entirely on an inventory of species in the district that he had accomplished by means of intense field explorations and data-building. This approach was a clear departure from contemporary district floras wherein the enumerations were, in

16 Cited in S. John Britto and S Karthikeyan, "Tireless Botanist and Environmentalist," Shola 33 (2004): 369-77, here 371 .

17 Britto, "Tireless Botanist and Environmentalist," 373.

18 Cecil J. Saldanha, S.J., and Dan H. Nicolson, eds., The Flora of Hassan District (New Delhi: Amerind, 1976). 
part at least, based on reports of earlier explorers or on specimens collected and archived in herbaria several decades earlier. Further, Saldanha succeeded in enhancing the authenticity and credibility of the data by involving renowned taxonomists and specialists, Drs. Dan H. Nicolson (Araceae), Frances M. Jarrett (Ferns), R. E. Holttum (Ferns) and P. Taylor (Lentibulariaceae) to contribute to this work. ${ }^{19}$

Flora of Karnataka in two volumes was prepared by Saldanha in spite of his two heart attacks. ${ }^{20}$ Volume 1 is the first "floras" with keys, illustrations, descriptions, nomenclatural citations and distribution notes covering the nineteen districts of the state. The present and subsequent volumes with over 3,400 species of flowering plants form a basic tool for scientific and sustained utilization of the higher plants in the state. Volume 2 covers twenty districts of the state dealing with forty-nine (numbers $65^{-112}$ ) families of flowering plants. According to Dr. Rao,

Although India has renowned institutions for Taxonomic research and excellent collection of specimens vouchered in several well-known Herbaria, we do not still have a comprehensive update of county's flora available in one single source. He had set a trend of mapping plant resources of larger regions in India. ${ }^{21}$

Flora of Karnataka was the first ever state-wide floristic exploration attempted between 1978 and 1996 under Saldanha's stewardship, which is partly published.

Cecil Saldanha was also involved in environmental studies. "Cecil Saldanha was a visionary. He worked hard to protect the environment, specially the Western Ghats," according to M. N. Jayaprakash, senior environmental officer, Karnataka State Pollution Control Board (кSрсв). ${ }^{22}$ He was invited by the government of Karnataka to prepare The Karnataka State of Environment Reports (both in English and Kannada) for the years 1983-84, 1984-85, 1985-86, 1990, and 1993. Saldanha held several responsibilities and positions. ${ }^{23} \mathrm{He}$ was a

19 K. Sankara Rao, personal communication. Cecil Saldanha, S.J., Flora of Karnataka, vol. 1: Magnoliaceae to Fabaceae (New Delhi: Oxford and ibh Publishing, 1996);

20 Saldanha, Flora of Karnataka, vol. 2: "Podostemaceae" to "Apiaceae" (New Delhi: Oxford and ibh Publishing, 1996).

21 Rao, Personal communication.

22 https://www.geni.com/people/Rev-Fr-Cecil-Saldanha-SJ-Ph-D/600oooooo7400310319 (accessed September 29, 2019).

23 Savarimuthu Ignacimuthu, S.J. "The Contributions of South Asian Jesuits to Environmental Work," Journal of Jesuit Studies 3 (2016): 619-44, here 630. 
member and chairperson in various state and central environmental commissions in the government of Karnataka for multidisciplinary environmental impact studies both for resource utilization and industrial development. His book Plants of India, co-authored with Jyotsna Dhawan (b.1955), has attractive pictures with aesthetic value, giving an insight into the biological diversity in the ever green, moist deciduous montane forests on the Western Ghats of peninsular India. ${ }^{24}$ There is an appeal for the conservation of these beautiful and unique plants for the future generations. His other works on environmental issues are Endemic Angiosperms in the Western Ghats; Geology and Soils of Western Ghats; A Select Bibliography on Environment of Karnataka; A Select Bibliography for Andaman and Nicobar Islands for Environmental Impact Assessment; Managing the Western Ghats, and Lakshadweep. ${ }^{25}$

Visuvasam Sousai Manickam (1941-2012) carried out extensive detailed fieldwork on the Pteridophytes of the Western Ghats from 1969 onwards. He was able to explore the entire Palni Hill range, surveying and collecting some 2,500 pteridophytes. ${ }^{26}$ This included correlating the distribution of ferns in the various phytogeographic zones of the Palni Hills to the micro- and macroclimate. During this work he investigated the cytology of about thirty-five species of ferns. The results were published in three books, Manickam and Ninan's Enumeration of Ferns of the Palni and Ecological Studies on the Fern Flora of the Palni Hills (S. India) (1984), and Manickam's Fern Flora of the Palni Hills (South India) (1986). Unlike his predecessors, he documented and numbered his collections conscientiously, providing the numbers and details in his publication, something that no other cytotaxonomists in India were doing at that time. His extensive later herbarium collections are preserved at St Xavier's $(\mathrm{XCH})$, and nearly all the important voucher-specimens of his and his students have been photographed there for preservation. ${ }^{27}$

24 Cecil Saldanha, S.J. and Jyotsna Dhawan, Plants of India (New Delhi: Oxford and ibh Publishing, 1984).

25 Cecil Saldanha S.J., Endemic Angiosperms in the Western Ghats (Bangalore: Centre for Taxonomic Studies, St Joseph's College, 1995); Saldanha, ed., A Select Bibliography for Andaman and Nicobar Islands for Environmental Impact Assessment, 2 vols. (Bangalore: Centre for Taxonomic Studies, St Joseph's College, 1988-9o); Saldanha, ed., A Select Bibliography on the Environment of Karnataka (Bangalore: Centre for Taxonomic Studies, St Joseph's College, 1995); Saldanha, Managing the Western Ghats (Bangalore: Centre for Taxonomic Studies, St Joseph's College, 2001).

26 Asir Benniamin and Chris Fraser-Jenkins, "Obituary:The Rev. Father Dr. V. S. Manickam S.J. (1944-2012)," American FernJournal 102, no. 3 (2012):236-39.

27 V. S. Manickam and C. A. Ninan, "Enumeration of the Palni Hills," Botanical Records and Monographs (Lucknow) 1 (1976): 1-153; Manickam, and Ninan, Ecological Studies on the 
During the years $1984-87$, funded by the Department of Science and Technology, Manickham carried out a major project on the biosystematics of ferns of the Western Ghats covering an area of 18,00o sq. km. and collecting some five thousand pteridophytes. Detailed field work was done in all the mountain ranges of Tamil Nadu and Kerala between Kanyakumari and Palghat. Assisted by his student, Dr. Varaprasatham Irudayaraj (b.196o), he investigated the cytology of 110 ferns collected from the area. Their cytological and taxonomic results were published in two books, Cytology of Ferns of the Western Ghats South India (1988) and the outstandingly useful, illustrated work, Pteridophyte Flora of the Western Ghats: South India (1992). ${ }^{28}$ In a second project, the Western Ghats were explored from Palghat to Coorg in Karnataka. Detailed fieldwork was carried out in the Nilgiris, Silent Valley, Wyanad and Coorg, collecting 3,500 specimens. As a part of this project, five families of ferns were subjected to preliminary phytochemical analysis by his research scholars. A third related project concentrated on re-exploring several of the higher mountains such as the Anamallays, Palnis, and Tirunelveli hills, resulting in a further book, Pteridophyte Flora of Nilgiris, South India. ${ }^{29}$ The Centre for Biodiversity and Biotechnology at St Xavier's Palayamkottai was set up by him in 1987. The Kodaikanal Botanic Garden, inaugurated on November 1999, comprises one hundred acres, where 175 fern species, about fifty orchids, and about twenty cacti are being cultivated. The garden includes about thirty acres of subtropical forest and about ten acres of undisturbed forest. ${ }^{30}$

Though politically not a part of India, Sri Lanka, formerly known as Ceylon, has been closely associated with it. Two Sri Lankan Jesuits who have worked in the field of biology are Louis Hermanegild Cramer (1924-2008), who studied the floral biodiversity of Sri Lanka and wrote a book on Sri Lankan flora, ${ }^{31}$ and

Fern Flora of the Palni Hills: South India (New Delhi: Today and Tomorrow's Printers and Publishers, 1984); Manickam, "Cytology of Thirty Species of Ferns from Palni Hills (South India)," Cytologia 49 (1984): 49-59.

28 V. S. Manickam and V. Irudayaraj, Cytology of Ferns of the Western Ghats (South India) (New Delhi: Today and Tomorrow's Printers and Publishers, 1988); Manickam and Irudayaraj, Pteridophyte Flora of the Western Ghats, South India (New Delhi: B.I. Publications, 1992).

29 V. S. Manickam and V. Irudayaraj, Pteridophyte Flora of Nilgiris, South India (Dehradun: Bishen Singh and Mahendrapal Sing, 2003), 1-192.

30 V. S. Manickam, "Rare and Endangered Ferns of Western Ghats of South India," Fern Gazette 15, no. 1 (1988): 1-10.

31 L. H. Cramer, S.J., The Revision of the Flora of Ceylon (Peradeniya: Botanical Society, University of Sri Lanka); Cramer, "Acanthaceae," in A Revised Handbook to the Flora of Ceylon, ed. M. D. Dassanayake (Rotterdam: A. A. Balkema, 1980), 12:1-140. 
Guy de Fontgalland Rajendram (b.1934), who has published several research papers on the biological control of insect pests by using beneficial natural enemies. ${ }^{32}$

\section{3}

\section{Contributions of Modern Biologists}

The Jesuits whose work has been reported till now have gone to their eternal reward. The age of classical biology has also come to an end. Biology is no longer only a descriptive science. With the integration of a range of interrelated techniques and biological processes for practical applications in agriculture, health care, and industry, biology has been transformed into biotechnology. Most of the advances have been made by privatized biotechnology research and development in developed countries using sophisticated technologies that are proprietary in nature. Most developing countries have to acquire valuable biotechnologies for improving agriculture, food, and pharmaceuticals from developed countries. To avoid being neo-colonized by such developments, developing countries need to have their own technologies. The work of the older Jesuits has been carried forward by younger Jesuits incorporating these changes applying modern biotechnological tools in their research. One of the younger Jesuits who have successfully made the transition from the classical to modern biology work is John Britto (b.1946) who, after the untimely passing away of Koyapillil Mathai Mathew, has carried forward his work at the Rapinat Herbarium.

The floras prepared by Matthew are being updated and revised using molecular systematics. A flora of central and north Tamil Nadu of flowering plants collected from actual field work is being prepared. The novelty of this flora is that for the first time Indian taxonomy will have a flora based on the latest angiosperm phylogeny classification (APG-IV 2016). This flora will be a trend setter for the other floras in India. ${ }^{33}$ In keeping with trends of development in World Herbaria Rapinat Herbarium (R HT) is creating a virtual herbarium.

32 G. F. Rajendram, "Some Problems Affecting Oviposition of Trichogramma Californicum in Artificial Media," Canadian Entomologist 110 (1978): 345-52; Rajendram and Devarajaha "Laboratory rearing of Cyrtorhinus lividipennis," Vnignanam Journal of Science 5 (1990) 14-21; Rajendram, "Population Sampling of Planthoppers, Leafhoppers and Insect Predators on Broadcast Rice Treated with Carbofuran in Eastern Sri Lanka," Insect Science and Its Application 15, no 2 (1994): 139-43.

33 S. John Britto, Molecular Systematics (Tiruchirappalli: Rapinat Herbarium, St. Joseph's College, 2004); Britto, Diversity of Plants: A Molecular Approach (Tiruchirappalli: Rapinat Herbarium, St. Joseph's College, 2009). 
Nearly three million mounted herbarium specimens have been digitized following the methodology designed by Royal Botanic Gardens, Kew. For the Global Jesuit Institutions this is a unique achievement. DNA barcoding has been introduced in RHT to submit to the Genbank.

RHT in collaboration with the Department of Space (ISRO) is conducting studies in vegetation mapping and study of forest cover in the Eastern and Western Ghats of India by the technology of remote sensing and GIs. ${ }^{34}$ In a network research, RHT is engaged in collaboration with Department of Biotechnology, Government of India (DBT) and ISRO on plant resource inventory and bioprospecting investigations. The Department of Space ISRO-Dehra Dun and Hyderabad together with RHT have undertaken research analysis of the carbon pool present in the forest cover of Tamilnadu in two phases. With assistance from the Ministry of Environment and Forests, RHT is engaged in reintroduction of endangered, threatened medicinal and economically useful plants, chiefly in the Eastern Ghats and the Palni hills.

RHT is documenting the ethnobotany of Irula tribals and Kuravas of Tiruvanamalai and Villupuram districts of Tamilnadu, the ethnobotany of Santals in the Burduwan District of West Bengal, Oraon tribals of Latehar District of Jharkhand, and Koraku tribals of Balrampur District of Chhattisgarh. The RHT team is now active in botanical authentication of medicinal plants with assistance from Indian Council of Medical Research (ICMR).

John Britto has also continued to create environment awareness through his Environmental Education Program at the Anglade Institute. This program has trained more than seventy thousand participants. Conservation research has also continued, like the Green Belt planting of more than two thousand acres, distributing over three million saplings.

Lancelot D'Cruz (b.1961) of St Xavier's College, Ahmedabad, has created a living laboratory for many undergraduate students through various projects such as Community Ecology and Succession projects, capturing phenology of plants and documenting changes. One of his research areas is ethnobotany. He has been actively involved in the commercialization of medicinal plants and ethnobotanical products by forming a group called Aadi Aushadi, thereby bringing a marked difference in the socioeconomic conditions of the less

34 S. John Britto, "Mapping and Monitoring Biodiversity Using Remote Sensing and Geographical Information System (GIS)," in Environment, Biodiversity and Bioethics Current Trends and Force Directions, ed. Francis P. Xavier et al. (Chennai: Loyola College, 2002), 29-24; Britto et al., "Quantitative Analysis of Non-Timber Forest Products in Four Forest Types of Pacchaimalai Hills Eastern Ghats of Tamil Nadu," Indian Forester 129, no. 4 (2003): 489-94. 
privileged. ${ }^{35} \mathrm{He}$ has developed people-forest-laboratory-industry linkages for socioeconomic development and the protection of traditional medicinal knowledge in the Dediapada forests of South Gujarat with the support of the Gujarat Ecology Commission. This involved the setting up of an interactive network of medicine men, the documentation in $\mathrm{CD}$-format of one hundred significant medicinal plants, setting up of five enclaves of medicinal plants in the vicinity of five tribal schools, and the use of these forests for environmental sensitization of tribal students. The conservation initiatives included the use of plant tissue culture for conservation of threatened ethnomedicinal plant species and ex situ conservation carried out at the St. Xavier's college campus in Ahmedabad. The native plants from Dediapada and their traditional uses as well as the demand in the Indian market were studied. A bio-prospecting study to assess the current situation of the native medicinal plants along with a market research study and business feasibility study was carried out. The project aims to enhance the capacities of the beneficiaries through a series of capacity building workshops on entrepreneurship, administrative functioning, participatory decision making, gender equality, health promotion, water harvesting skills, etc. The community linkages in the area and the traditional medicine systems are being strengthened through organizing workshops for school children and local groups linked to the establishment of medicinal plant forests in three tribal schools. ${ }^{36}$ Based on this initiative, the Gujarat state government signed the first access benefit sharing agreement under the Gujarat Biodiversity Act with Aadi Aushadhi. This project, furthermore, is preparing seventeen equivalent programs under the rubric of the People's Biodiversity Registers, based on the model of Aadi Aushadi.

Savarimuthu Ignacimuthu (b.1948) was the director of the Entomology Research Institute, Loyola College, Chennai, and presently is working in St Xavier's College, Palayamkottai. A researcher in plant biotechnology, Ignacimuthu's prime interest was to identify useful characteristics in the wild genetic resources of legumes that people used in food preparations. His idea was to see if the useful genes in the wild varieties could be introduced into the cultivated varieties, so that they became hardier or more productive or gain other beneficial characteristics. He has been conferred the Tamil Nadu Scientist Award, popularly known as the TANSA award, in recognition of this work.

35 See Lancelot D'Cruz, S.J., "Traditional Knowledge and NTFP Utilization: The Aadi Aushadhi Model," Biodiversity Watch 1 (2013): 71-78; Aadi Aushadhi Group, http://aadiaushadhi .com (accessed October 4, 2019).

36 http://www.biodiversity-watch.com/issue/Biodiversity_Watch_issue_1.pdf (accessed October 4, 2019). 
Ignacimuthu has published several papers and books on insect pest management and biopesticides ${ }^{37}$ as well as on environmental awareness especially for school children and villagers. ${ }^{38}$ His Tamil book on environmental awareness got the best book award from Tamil Nadu Government in 1995 .

The Royal Entomological Society, London, made Ignacimuthu a fellow of the Royal Entomological Society (FRES) for his outstanding contributions in entomology. He is also a fellow of National Academy of Agricultural Sciences, New Delhi. He is scientist emeritus of CSIR and ICMR, New Delhi. He also holds many patents. One insect species is named after him (Jacthrips ignacimuthui), and so is one molecule (Ignaciomycin). ${ }^{39}$

Vincent Joaquim Braganza (b.1950), director of the Loyola Centre for Research and Development (LCRD), Ahmedabad, has several, projects to address poverty alleviation. ${ }^{40}$ One of these is the production of propagules of Curculigo orchioides for distribution to tribals for large scale cultivation of the plant. His team has achieved bulbil production in liquid media reducing costs of production by nearly eighty percent The tribals have undergone training for learning to handle every equipment related to their work such as autoclave, laminar air flow, weighing balance, $\mathrm{pH}$ meter etc. Moreover, they know media composition, hormone concentration, and maintaining sterility of the growth room. The other projects are production of Rhamnolipid from Pseudmonas aeruginosa, production of mycophenolic acid (MPA) by Penicillium brevicompactum using solid state fermentation, utilization of thermophilic bacterial consortium, preparation of a kit for biosulphidogenesis and their

37 Savarimuthu Ignacimuthu, S.J. and Alok Sen, eds., Biopesticides in Insect Pest Management (New Delhi: Phoenix Publishing House, 1999); Ignacimuthu and Jayaraj, eds., Biodiversity and Insect Pest Management (New Delhi-Oxford: Narosa Publishing House-Alpha Science, 2006); Ignacimuthu and Jayaraj, eds., Biotechnology and Insect Pest Management (New Delhi: Phoenix Publishing House, 2007); Ignacimuthu and Jayaraj, eds., Recent Trends in Insect Pest Management (New Delhi: Elite Publishing House, 2008); Ignacimuthu and Vasantharaj, eds., Eco-Friendly Insect Pest Management (New Delhi: Elite Publishing House, 2009); Ignacimuthu and Vasantharaj, eds., Non-Chemical Insect Pest Management (New Delhi: Elite Publishing House, 2010).

38 Savarimuthu Ignacimuthu, S.J., Environmental Awareness and Protection (New Delhi: Phoenix Publishing House, 1998); Ignacimuthu, Environmental Science (New Delhi: Phoenix Publishing House, 2003); Ignacimuthu, Ecology and Environment (New Delhi: Elite Publishing House, 2006); Ignacimuthu, Environmental Studies (Chennai: M. J. P. Publishers, 2012).

39 E.g., see Indian patent no. $657 /$ che $/ 2006$.

40 Vincent Joaquim Braganza, ed., Annual Report Loyola Centre for Research and Development 2016-2017 (Ahmedabad: Xavier Research Foundation, 2018). 
bioaccumulation in industrial effluent treatment, and low-cost production of ferulic acid. His team is also working on cost effective protease production and chitin production. They are working on local microalgae for biodiesel production and the utilization of thermophilic bacteria for industrial effluent treatment. ${ }^{41}$ Braganza has developed a biodiversity park of native and exotic trees on the campus of St Xavier's College, Ahmedabad, in collaboration with the Xavier Research Foundation. The park has nearly one thousand plant species of ethnomedicinal, medicinal, and economic importance. It has an excellent collection of cacti. To reach its environmental objective, this collaboration provides source material for plant tissue culture as a repertoire of techniques for conserving, propagating, and promoting several threatened species of plants, particularly those with medicinal potential. The students of St Xavier's College have been trained to start a company of their own "Xplant" to produce and market tissue culture produced plants. ${ }^{42}$ Braganza is involved in research education and extension work in biology and has brought out several booklets on environmental issues in the local language for schools and colleges.

Melwyn D'Cunha (b.1970) at St Aloysius College, Mangalore, studied the association of Cannavelia, a leguminous plant of the coastal dunes with various Mycorrhizal fungi ${ }^{43} \mathrm{He}$ also studied the possibility of using the plant as source of nutrition for animals and humans. In association with the Royal Technical Institute of Sweden, Stockholm, he investigated the ultrastructure of the mycorrhizal spores. ${ }^{44}$ D'Cunha successfully raised around one thousand saplings of two fruit bearing trees, Terminalia catalpa (Sea Almond or Tropical Almond) and Calophyllum inophyllum, which are planted in and around the Mangalore area.

He also initiated and managed a pilot plant for food processing under the Ministry of Food Processing Industries (MFPI), Government of India, especially to process the local fruits and vegetables. Under his stewardship the Department of Food Science organized several food processing workshops for the students and the public at large. After his transfer to St Joseph's College, Bengaluru, D'Cunha initiated biodiversity studies on campus with the assistance

41 Sudha Sahay and Vincent J Braganza, "Microalgae Based Biodiesel Production: Current and Future Scenario," Journal of Experimental Sciences 7 (2016): 31-35.

Savarimuthu Ignacimuthu, S.J., "The Contributions of South Asian Jesuits to Environmental Work," Journal of Jesuit Studies 3, no. 4 (2016): 619-44, here 627; https://brill.com/view/ journals/jjs/3/4/article-p619_5.xml (accessed October 4, 2019).

M. D'Cunha and K.R. Sridhar, "Micropropagation of Canavalia cathartica of Coastal Sand Dunes," Journal of Agricultural Technology 7, no. 1 (2011): 85-96.

44 Ignacimuthu, "The Contributions of South Asian Jesuits to Environmental Work," 631. 
of staff and students in collaboration with the Indian Institute of Science, Bengaluru. Mapping the campus has resulted in data on the need for a carbon sequestration process by enhancing green vegetation on campus. The Bengaluru City Corporation has invited St Joseph's College to be a part of its tree mapping project of the city. The college has taken up the initiative to prepare seed balls in collaboration with the forest department so as to participate in the afforestation project of the forest department.

Leo D'Souza is a pioneer in plant tissue culture in India and has worked out protocols for the large scale in vitro propagation of several forest trees like Ailanthus malabarica, Butea monosperma, and Xanthozylum, ornamental trees like Millingtonia hortensis, Lagerstroemia flos reginae, and a wild fern Drynaria quercifolia. ${ }^{45}$ Ayurveda, the Indian medicinal system, is plant based. The plants used as medicine are dwindling and some are no longer available because of the destruction of their habitat. The team of D'Souza has worked out protocols for micropropagation of three medicinal plants, Curculigo, Murraya, and Vernonia used in Ayurveda. The district has a rare ancient plant, a living fossil Gnetum. This is dying out as it has no commercial use. The team has succeeded in getting somatic embryos of this rare plant. With the support from the Department of Biotechnology, Government of India, the team has succeeded in regenerating a red listed medicinal plant Coscinium fenestratum and has reintroduced it into the forest with the help of the Forest Research Department of Kodagu. Eleusine coracona (ragi, finger millet), an orphan crop and underutilized crop resource has been multiplied in vitro.

Transformation studies using particle gun bombardment and agrobacterium mediated transformation of cashew using a marker gene was carried out to study the possibility of producing a pest resistant variety of cashew in order to reduce aerial spraying of pesticides on cashew plantations, which contaminates the environment, posing a potential health hazard. ${ }^{46}$ Successful transformation of Capsicum annuum L. (chilli) has been achieved to obtain virus resistant plants. Radiation induced in vitro mutagenesis of ornamental plant Zinnia has been worked on, and some novel varieties of Zinnia in both color and morphology have been produced. ${ }^{47}$ Studies on the biodiversity of local varieties of

\footnotetext{
45 Hegde Smith et al., "Pathways in Plant Tissue Culture," in Biotechnology: Challenges and Prospects, ed. Leo D’Souza et al. (Mangalore: SAC Publications, 2003), 13-23.

46 Shaahi Kiran Nivas et al., "Agrobacterium Mediated Transformation of Anacardium occidentale L (Cashew) Using G F P Markers System," Acta horticulturae 738 (2007): 467-72.

47 Balla Pallavi et al., "Gamma Rays Induced Variations in Seed Germination, Growth and Phenotypic Characteristics of Zinnia elegans var. Dreamland," Advances in Horticultural Science 31, no. 4 (2017): 267-73.
} 
rice, sugarcane, and ragi using molecular markers have been conducted. Presently, studies are being done to understand various pathways involved in plant tissue culture. Global proteomic analysis is carried out using high-resolution mass spectrometer to analyze various upregulated and downregulated proteins to understand the mechanism behind the morphogenesis in plants.

The team has also been involved in algal biomass production since 2010. The focus is on alternative energy sources and the prospective use of algae as a source of biofuel and sustainable energy. In addition to biofuel work on algae, the generation of high-value products from the lipids so derived is also being done. ${ }^{48}$ D'Souza has also carried out a study of the effects of large-scale deforestation on soil, flora, and fauna of the district. He has also studied the ill effects of afforestation being done with non-native trees, which causes considerable imbalance to the local environment. In association with the Sociology Department of the college, he also studied the socio-economic effects of such changes in village life, especially with regard to occupation of persons who depend on forest produce for their work and livelihood. ${ }^{49}$

Even though many Jesuits are not formally working in the area of biology, they are creating awareness on environmental issues.

Sebastian Emmanuel (b.1955), as the editor of The Rally, a monthly periodical of the All India Catholic University Students Federation, takes up an environmental topic in each issue to encourage his readership to be aware of environmental issues. ${ }^{50}$

Puthuparambil Antony Chacko (b.1954), along with other Jesuits in the Dumka province, took steps to expose tribal and indigenous students to their immediate environs, especially the hills and forest canopy, through classes, dramas, environmental readings, and direct experience. As an outcome of this program, students began to sing songs about the environment and to take up various creative projects, such as writing an autobiography of a stream, a plant, a butterfly—to name some examples. Additionally, he facilitated the creation

48 Severes Alifha et al., "Use of Light Emitting Diodes (LEDs) for Enhanced Lipid Production in Micro-Algae Based Biofuels," Journal of Photochemistry Photobiology (B) 170 (2017): $235-40$.

5o Sebastian Emmanuel, S.J., Periavaruna Vishleshana [Environmental analysis] (Vijayawada: Andhra Jesuit Social Action, 1993). 
of a students' association, the Environmental Protection Group, to protect the forests from further devastation; in fact, as a result of this program, not a single tree appears to have been fallen since its founding. Acting in public interest for environmental justice and promoting the survival of the area's indigent population, these students collaborated with the regional governing authorities in order to preserve several tracts of forest. ${ }^{51}$

Kumbalankal Chandy (b.1946) is involved in cultivating popular awareness about ecosystems, ecology, and the environment in the Indian public sphere. As the founder of the Department of Agriculture and Environmental Education at the Indian Social Institute, in New Delhi, he has written 676 booklets about eighty topics that are related to subjects ranging from agriculture, animal husbandry forestry, fisheries, to aquaculture. ${ }^{52}$

Sahajeevanam, established by the Jesuits of the Kerala province, is a center for cultivating environmental awareness and sustainable growth by mobilizing popular participation in projects of environmental preservation, conservation campaigns, social justice advocacy, particularly on behalf of the poor. ${ }^{53}$

Joseph Xavier (b.1961) is the main author of the humanitarian research project, Weaving Hopes after Disasters, in collaboration with the Indian Social Institute, Caritas India, and the Indo-Global Social Service Society, with the support of Caritas Germany. ${ }^{54}$

\section{5}

\section{Conclusion}

The contributions of Jesuits in India in the field of research in science is carried out not only as an academic exercise but also as a mission. ${ }^{55}$ One of the important reasons for working in scientific research in India is that there is a need to make the church present in the world of intellectuals. Scientific research is

$5^{1} \quad$ Ignacimuthu, "Contributions of South Asian Jesuits to Environmental Work," 625.

52 Kumbalankal Chandy, Agriculture Education Series (New Delhi: Indian Social Institute, 1992-95).

53 Ignacimuthu, "Contributions of South Asian Jesuits to Environmental Work," 632.

54 Joseph Xavier, S.J. et al., Weaving Hopes after Disasters: Long-Term Impact and Beneficiary Satisfaction of Relief; Rehabilitation and Development Programs in India (New Delhi: Indian Social Institute, 2015).

55 K. M. Mathew, "My Scientific and Environmental Apostolate," Caritas (Dindigul) 1 (1983): 24-37. Savarimuthu Ignacimuthu, "My Mission through Scientific Research," Omega 14, no. 1 (2015): 110-25. Leo D'Souza, "To Make the Church Present in Science," Jivan 16 (1999): 7 . 
therefore strongly recommended by popes ${ }^{56}$ and by the superiors general of the society. ${ }^{57}$ The presence of the church in intellectual circles in Europe is ensured by theologians and philosophers. Jesuits make an enormous contribution to the intellectual field, and because of this they are regarded with respect. In India, Christian theologians and philosophers are confined to the Christian world and the seminary. Their ideas do not influence the non-Christian world and hence do not make any impression on it. Christians are respected for their educational and social work, but the intellectuals, the vast majority of whom are non-Christians, do not have any common field to interface with Christian intellectuals. Any contribution in the research field, however minuscule, will serve to make the presence of the church felt in a small way. ${ }^{58}$ The limitation in quantity, however, has to be made up by the quality of research done and its relevance to society.

This essay shows that the contributions of Jesuits to biology in India has been recognized, appreciated, and supported by the scientific community. Their work has been presented in peer-reviewed, high-impact international journals and at various national seminars and international conferences where they have been specially appreciated. The social relevance of the research projects is an important criterion to judge the utility of research work to society. As most of the research done by Jesuits in India is for poverty alleviation or for environmental conservation, their work has been recognized and funded by important national funding bodies. The non-biologists have contributed to disseminating the fruits of the labor of biologists by making environmental awareness a part of their ministry. Collaboration with other institutions of national and international importance is also an important aspect of their research. Various private and government bodies have lauded their contributions in glowing terms and acknowledged their work with awards and citations.

$5^{6} \quad$ "We are aware of the importance of the intellectual apostolate for the life and the mission of the Church today," General Congregation 35, D 1, § 13; Benedict XVI, Allocution to the 35th General Congregation of the Society of Jesus (February 21, 2008), §4.

57 Adolfo Nicolás, Allocution to the Holy Father during His Audience to the Fathers of the $35^{\text {th }}$ General Congregation (February 21, 2008), § 2; "The Congregation calls for a strengthening and renewal of this ( intellectual) apostolate as a privileged means for the Society to respond adequately to the important contribution to which the Church calls us." Decree on mission, GC 35; Arturo Sosa, SJ Europe - Call for networking in Jesuit higher education, https://jesuits.eu $>$ News 27.02.2017; http://sjweb.info/news/index.cfm?Tab=11\&publang=1\& pubtextid=18095\&pubid=15784 (accessed October 22, 2019).

D'Souza, "To Make the Church Present in Science," 7. 


\section{Acknowledgments}

The input of various Jesuits about their research work are gratefully acknowledged. Thanks are due to the members of the team of the Laboratory of Applied Biology, Shashikiran Nivas, Alifha Severes, Sachin Patavardhan, Sulakshana K., and Shivananda for their help in preparing the manuscript. 